\title{
The Extent to which Grade 4 English First Additional Language Workbooks Cater for Learners' Multiple Intelligences
}

\author{
Lucy Sibanda \\ Department of Human Sciences, Sol Plaatje University, Kimberley, South Africa
}

Received August 18, 2021; Revised December 2, 2021; Accepted December 27, 2021

\section{Cite This Paper in the following Citation Styles}

(a): [1] Lucy Sibanda, "The Extent to which Grade 4 English First Additional Language Workbooks Cater for Learners' Multiple Intelligences," Universal Journal of Educational Research, Vol. 10, No. 3, pp. 185 - 194, 2022. DOI: 10.13189/ujer.2022.100301.

(b): Lucy Sibanda (2022). The Extent to which Grade 4 English First Additional Language Workbooks Cater for Learners' Multiple Intelligences. Universal Journal of Educational Research, 10(3), 185 - 194. DOI: 10.13189/ujer.2022.100301.

Copyright $\bigcirc 2022$ by authors, all rights reserved. Authors agree that this article remains permanently open access under the terms of the Creative Commons Attribution License 4.0 International License

\begin{abstract}
One efficient way through which learners can achieve learning outcomes is the implementation of multiple intelligences, which was proposed by Gardner in 1983. Gardner postulates that individuals have eight clear intellectual potentials which work together to survive in the world, all of which should be developed in the classroom. The study aims to establish manifestations of multiple intelligences in Grade 4 English First Additional Language workbooks currently in use in South African schools, especially as reflected in the teaching and learning activities given to the learners. Since the ubiquitous workbooks are vital in the presentation of educational curriculum in the South African contexts, their reflection of multiple intelligences would optimize diverse learners' content reception and retention. The cognitive profile was largely intrapersonal and verbal-linguistic, according to a content analysis of the two 2021 Grade 4 English FAL workbooks. The type of intelligence that was identified least was the naturalistic intelligence, while the musical intelligence was completely missing. There was no equitable or balanced distribution or reflection of intelligence types in each of the workbooks. It is recommended that textbook/workbook writers and teachers infuse in their instructional material, activities that serve all the intelligences of learners. In such manner, no learner is left behind as everyone's learning style is accommodated, and instruction is rendered at the learners' own terms and not the instructors' convenience.
\end{abstract}

Keywords Multiple Intelligences, Workbook, Learning Styles, Collaboration

\section{Introduction}

Over the last three decades, there has been a surge in interest in determining whether teachers and textbook authors use multiple intelligences in their teaching and learning activities [1-6]. Gardner's theory of multiple intelligences [7] has had a significant impact on educational systems around the world. In a nutshell, this theory states that each person has different learning styles or intelligences that they use to acquire knowledge. Gardner [7] identified seven intelligences in humans, and the naturalistic intelligence was eventually classified as the eighth [8].

Previous studies around the world have primarily explored English as a Foreign Language (EFL) teachers' familiarity and experiences with Multiple Intelligences theory [9-12]. Other studies have analysed the differences of multiple intelligences between males and females of elementary school [13]. Researchers have also researched the multiple intelligences theory and its influence in language classrooms [4,14-21].

In South Africa, scant literature has been published on the use of multiple intelligences in teaching and learning. 
These studies include Maphalala and Mpofu's 2017 study which explored possible assessment opportunities in the South African Curriculum and Assessment Policy Statement (CAPS) for Senior Phase through Gardner's theory of multiple intelligences based on an analysis of literature. The scrutiny of literature and the Senior Phase syllabus shows that Gardener's eight multiple intelligences for holistic learner assessment were integrated [22]. In another study, [23] studied the impact of a viewpoint that is based on Gardner's theory of multiple intelligences on teachers, learners, and learners' performance. Findings showed that a multiple intelligence approach to teaching had a positive impact on learners' behaviour and educational accomplishment. In another study, [24] suggest particular ways in which teachers can integrate the various intelligences as they teach and as learners get involved in different learning activities in the mathematics classroom. [25] also discusses both Gardner's multiple intelligences theory and outcomes-based education in South Africa because the assumption was that both could resolve the present challenges in the education of South African [25, p. 61]. In another study, [26] describes the Heads of Departments experiences of their schools, in relation to whether teachers implemented multiple intelligences in their lessons, and how that impacted both teachers and learners. The studies carried out in South Africa covered diverse issues on multiple intelligences.

Several attempts have been made to investigate how multiple intelligences are implemented in textbooks and learning materials that are used by learners in schools around the world [1, 22, 27-31]. Because textbooks play such an important part in curriculum development, textbooks and workbooks now in use in schools must represent and activate as many intelligences as possible in order to satisfy the learning styles of students. There has, however, been a dearth of studies interrogating the extent to which current textbooks and workbooks used in South African schools have capitalised on these multiple intelligences in the activities given to learners. The one-size-fits all teaching and learning materials should, at the very least, cater for learning diversity in among learners. This study, therefore, intends to interrogate the extent to which the current two English FAL workbooks, used in the South African school education system at Grade 4 level, reflect the multiple intelligences.

This study seeks to address the research question:

To what extent do the two Grade 4 English First Additional workbooks currently used in South African schools reflect all the multiple intelligences?

\section{The Multiple Intelligence Theory}

The multiple intelligence theory was proposed by [8] who defines intelligence as a "biopsychological potential to process information that can be activated in a cultural setting to solve problems or create products that are of value in a culture." All people are born with the eight intelligences, and all children come into the classroom with various intelligences that have already developed, which decide the strength and weakness of a learner's intellectual, and the ease or difficulty information becomes when it is presented in a specific way [8].

People do not learn in the same way [8]. Each person owns to an extent, each intelligence, but each always has a dominating intelligence. All the intelligences are equally important. The intelligences are used simultaneously and generally work together, as individuals develop skills or solve problems. According to [32] regardless of which subject a teacher teaches, whether in the arts, science, history, or mathematics field; the teacher should present learning materials in numerous ways, so that diverse intelligences complement each other. Because each person differs from another, there is no logic in teaching and assessing learners in the same way, like in the traditional way of learning in schools, where most focus is put on linguistic and logical-mathematical intelligences.

Gardner [7] initially proposed seven abilities that manifest multiple intelligences which are: visual-spatial, verbal-linguistic, musical-rhythmic, logical-mathematical, interpersonal, intrapersonal, bodily-kinesthetic, and later added naturalistic intelligence. Following are the descriptions of the different intelligences.

Verbal-linguistic intelligence: "Involves sensitivity to spoken and written language, the ability to learn languages, and the capacity to use language to accomplish particular goals," according to 33, p. 41 . It has to do with one's ability to think and solve difficulties using language. Learners that are verbal-linguistic are good at speaking and expressing themselves in words [33]. They have excellent writing and speaking skills. They utilize words to persuade, argue, entertain, and educate. Language is linked to verbal-linguistic intelligence. It is explicitly described as the ability to speak and write coherently and eloquently by [34] and [35]. [36] suggest that in order to learn a language well, students must have strong listening, reading, writing, and speaking skills. Learners who lack the four language skills struggle to comprehend what they read [37]. It may be argued that learners' linguistic knowledge was best determined by their verbal-linguistic intelligence [38]. Brainstorming, choral reading, debating, individualized reading, journal keeping, discussing in large and small groups, reading to the class, sharing time, storytelling, writing a newspaper article, writing in a learning journal, making a book, and many other activities for verbal-linguistic intelligence learners take place in the classroom [39]. At some level, everyone is assumed to have this intellect.

Logical-mathematical intelligence: Gardner [33, p. 42] describes logical-mathematical intelligence as "the ability to examine problems rationally, carry out mathematical operations, and research difficulties scientifically." It has to do with the ability to think in abstract and conceptual terms, as well as the ability to recognize logical and 
numerical patterns [40]. Learners who are logical-mathematical appreciate working with numbers. They are adept at deciphering data and analyzing abstract patterns [33]. They think in terms of cause and effect, induction, and deductions, organizing/outlining, making steps, playing strategy games, thinking abstractly and utilizing symbols, and employing [41]. [42] claims that logical-mathematical intelligence can improve a learner's active learning by motivating them to be self-sufficient.

Visual-spatial intelligence: According to [33, p. 42], visual-spatial intelligence entails the ability to recognize and manage "patterns of large space as well as patterns of more constrained areas (such as those of chess players, graphic designers, or architects)." It has to do with the ability to think in pictures and images, as well as the ability to visualize precisely and abstractly [8]. Learners with high spatial intelligence think in pictures and images and process information in pictures and images [43]. They have great fine motor skills as well as excellent visual receptive skills [44]. These students can read maps and jigsaw puzzles, think in pictures, construct mental images, and love looking at maps, charts, and photos as well as viewing videos and movies [44]. Various tasks, such as varied uses of diagrams, concept mapping, or photographs, successfully assist learners who excel in visual-spatial intelligence to have a solid sense of interpreting visual imagery when it comes to second language learning and teaching [45], as well as in mathematics [46].

Bodily-kinaesthetic intelligence: [33, p. 42] describes bodily-kinaesthetic intelligence as the ability to "use one's entire body or sections of the body (such as the hand or the mouth) to solve issues or fashion goods." Through touch and movement, bodily-kinaesthetic learners are acutely aware of their surroundings. Young children process the world by absorbing information with their body, which subsequently creates the foundation for abstract reasoning. During this time, youngsters are better able to grasp a lesson that includes an active physical component [47]. Traditional modes of teaching can frequently distract or annoy a kid, but motions can often motivate and connect them, allowing the child to combine thought and movement through kinaesthetic learning in the classroom [48].

Musical intelligence: Musical intelligence, according to [33], entails the ability to recognize sound patterns, produce, convey, and comprehend sound-based meanings. It is characterized by auditory imagery and so requires competence in the performance, composition, and perception of musical patterns [49]. Musical learners use sound to think, feel, and process knowledge. They are better at perceiving, composing, and/or performing music. Other cognitive activities such as visual-spatial skills, abstract mathematical abilities, perceptual organization, reading skills, vocabulary retention, and linguistic abilities, i.e. translating thought into sound memory in general, are all influenced by music, according to studies by [50]. Musical intelligence, like all intelligences, can be used as a form or method of learning as well as a message or material to be taught [7]. The neuronal developments of the human brain, according to [51], demonstrate the cognitive capacity that characterizes musical intelligence. When working with children and teenagers in the classroom, using music can help manage their emotional states, enhancing interpersonal ties among the learner's body and between the learner and the teacher [52]. Participating in musical activities can help youngsters develop their reasoning and problem-solving skills, as well as their lateral thinking, memory, social skills, and teamwork abilities [52]. Structured musical instruction aids in the development of phonemic awareness, auditory and rhythmic discrimination, and reading ability in children [53]. They also say that incorporating music into language instruction helps students improve their reading, writing, listening, and speaking skills [53].

Interpersonal intelligence: Interpersonal intelligence refers to "a person's ability to comprehend other people's intents, motives, and objectives and, as a result, to work effectively with others" [33]. Learners with high interpersonal intelligence have an innate ability to effectively communicate with, relate to, and get along with others [54]. Because interpersonal intelligence is linked to the learning objectives of communication and collaboration, as well as critical thinking and problem solving [55], it is crucial for learning. Learners can display interpersonal intelligence in a course by presenting presentations, participating in group discussions, conducting experiments, and debating in small groups. Learners can share information and have a deeper comprehension of what they've studied thanks to small social groups and learner-centered activities. As a result, learners obtain intelligible input through working jointly in such a comfortable and non-threatening learning environment marked by contextual signals ([56].

Intrapersonal intelligence: "The ability to comprehend oneself, to have an effective working model of oneself-including one's desires, anxieties, and capacities - and to apply such information successfully in managing one's own life" [33, p. 43]. It has to do with one's ability to be self-conscious and aware of one's own inner sentiments, values, beliefs, and thought processes [7]. Intrapersonal intelligence learners are acutely aware of their feelings, ideas, and objectives. Such students typically require alone time to process and develop. Individuals with high intelligence have developed a strong feeling of self-assurance, independence, and willpower [7]. Keeping a journal, writing an autobiography, working independently, rewriting a story from their point of view, meditating sessions for brainstorming or studying, and making a scrapbook for their poems, papers, and reflections are some of the activities that are done in classrooms to promote intrapersonal intelligence [49].

Naturalist intelligence: The ability to locate oneself in the natural environment is referred to as naturalist intelligence [57]. It has to do with the ability to identify 
and classify plants, animals, and other natural objects. This intelligence refers to a person's natural curiosity about the world around them. These people appreciate being outside in nature and wish to keep it clean [58]. Plants, animals, and rocks are easily recognized and categorised by learners with good naturalistic intelligence [58]. Caring for classroom plants and pets, sorting and classifying natural objects such as leaves and rocks, researching animal habitats, observing natural surroundings, organizing or participating in park/playground clean-ups, recycling drives, and beautification projects, and researching a particular plant or animal are some of the activities done to promote this intelligence [59].

\section{Multiple intelligence and classroom teaching and learning}

This theory, when applied to the educational system, suggests that presenting numerous activities and approaches to learning helps and encourages learners to think about issues from various viewpoints, hence enhancing their understanding of that topic [60]. [61] also claims that giving students various access points to knowledge promotes learning. Detail knowledge about students' unique skills, needs, and opportunities for improvement should inform teaching and practice as much as feasible [62]. Schools should abandon the old method of dry lecturing and tedious reading of workbooks and textbooks in favor of using various intelligences. As a result, [60] believes that teachers should stop teaching and grading students in the same way because they learn in various ways.

The theory of multiple intelligences is significant because it broadens our understanding of accessible teaching and learning tools beyond the traditional verbal and logical approaches employed in most classrooms (e.g. lectures, textbooks, writing assignments, formulas, and so on) [63]. This means that textbook authors and teachers should design and present learning activities in such a way that they engage most or all of the intelligences. This type of presentation of most or all of the intelligences not only motivates students to study, but also allows teachers to reinforce the same subject in a variety of ways. As a result, what is being taught is better grasped.

Curriculum, education, classroom activities, and assessment procedures have all been based on Gardner's theory of multiple intelligences. According to [58], everyone has strengths and weaknesses in different intelligences, which is why teachers should consider how best to provide teaching and learning material for each subject and each class of students. Instruction that is geared to help students acquire content in a variety of ways can boost their confidence and help them improve in areas where they are weak. As a result, when education incorporates a diversity of meaningful and suitable techniques, activities, and assessments, learners' learning improves.

[64] and [65] argue that multiple intelligence theory is important in the teaching of language skills because it encourages learners to enhance their attitude, comprehension, motivation, and language competency by facilitating the use of metacognitive and cognitive methods. However, it is regrettable that diverse learning styles and intelligences are not valued equally, resulting in the loss of talents and skills among the youth.

An examination of the Grade 4 FAL workbooks is necessary since workbooks are the most important resources utilized by students in language classes, and as such, they play a critical role in communicating curriculum objectives to students with the support of teachers. Workbooks were chosen for this study because they have a broad reach in the South African setting, as they are freely distributed by the Department of Basic Education and can be the only source of classroom input for some students [66]. Grade 4 was chosen because it is a significant transitional stage highlighted by various changes, such as an increase in learning areas, a shift in instructional language, and a move from acquiring reading abilities to applying reading skills to study [67]. Because learners have different intelligences and learn in different ways, it's critical that workbooks cover the various intelligences as much as possible and adapt to the needs of all learners who use them. Because of their widespread use in South African schools, workbooks were chosen for this study. Because they are provided by the education department to all students, they were favored over textbooks, which are shared by students and are not always available to all students.

This study seeks to answer the research question:

To what extent do the two Grade 4 English First Additional workbooks currently used in South African schools reflect all the multiple intelligences?

\section{The scope and Importance of Workbooks}

Workbooks, like textbooks, are very essential learning tools in South Africa. The South African Department of Basic Education (DBE) began producing and disseminating workbooks in 2011 as an additional support for instructors (68). This was done as part of an intervention strategy to address poor students' performance in schools. As a result, textbooks and numeracy and literacy workbooks are created and distributed to all students in grades 1 through 9 (69). Learners' learning activities are organized in the workbooks (68). "Workbooks complement rather than replace textbooks by allowing learners to work in them," notes (70). When comparing workbooks to textbooks, workbooks become a very important learning tool because every Grade 1 to 9 learner has the same workbook across the country, whereas textbooks may differ from school to school because there are many textbooks on the market, and a school chooses a textbook for their school, which 
may be different from what the next school is using. Workbooks are sometimes the only source of reading material for some students in schools with low resources (70). As a result, workbook research becomes extremely crucial.

The workbooks are designed to aid in the teaching of mathematics and literacy, as well as to improve students' performance in these disciplines (71). While textbooks are designed to supplement what the teacher teaches in class, learners can use their textbooks to complete the tasks in separate exercise books, which feature exercises and activities, according to (72). The purpose of these exercises and activities is to see if the students understand the curriculum. As a result, the exercises in the workbooks match what students learn in class, and students complete the activities in the workbooks on their own. The worksheets are utilized in conjunction with the recommended textbooks, resulting in very effective learning resources. This means they have access to the curriculum content found in textbooks, as well as exercises to aid in "processing, consolidating, and absorbing that content" (72). Workbooks are referred to as fundamental LTSM (learning and teaching support material) by 72 . A textbook/learner book, workbook, and instructor guide are all essential instructional tools. Every year, the workbooks are updated to correspond with the official national curriculum.

A number of academics have conducted research on these workbooks. (73) looked at the Department of Basic Education workbooks for Grade 3 as curriculum tools to see how well they aligned with the official national curriculum, and discovered that the workbooks are best used as a practice curriculum tool. (74) conducted a case study of six grade 3 teachers' usage of Department of Basic Education workbooks and discovered that the teachers under study did not use the workbooks in the ways that the DBE intended, recommending that education programs train teachers on how to best use the workbooks. (70) investigates the degree of linguistic complexity in texts from grade 3 to grade 4 workbooks, finding a significant rise in textual complexity across all factors examined. (71) A study found that Grade 6 students improved their arithmetic skills when they used a traditional textbook in the same way they did when they used a workbook designed expressly to address South African students' low performance.

As a result of seeing how workbooks are utilized by all students in public schools, who sometimes do not have textbooks due to a lack of resources, and in resource-stressed contexts, workbooks are sometimes the only source of reading material for some students. It's crucial to identify manifestations of multiple intelligences in the workbooks now in use in South African classrooms so that we can assess how effective they are at allowing various learners to learn using different intelligences.

\section{Materials and Methods}

\subsection{Workbook Sample Selection}

The focus of the study is on two workbooks that are in use in Grade 4. The two workbooks selected are for English First Additional Language (FAL). English FAL was chosen instead of English Home Language (HL) because more learners in South Africa are registered for it. According to the Department of Education (2005), the FAL assumes that learners do not have adequate knowledge of the language they are learning. The FAL refers to a language that is not a mother tongue but which is the medium of learning and teaching in education (DoE, 2005). In South Africa, Grade 4 is an entrance to a new phase, the Intermediate Phase (Grade 3 to 6), which comes after the Foundation Phase (Grade 1 to 3). Grade 4 is a vital period in South African education, as it is in many other worldwide education systems, where learners make substantial transfers from the Foundation Phase (FP). Learners in the FP are working to improve their reading skills and art, but in Grade 4, they are expected to learn from what they read. The mechanics of reading, which underpin learning to read, are reportedly refined in the FP and used to retrieve information from readings in English in Grade 4.

\subsection{Analysis of the Workbooks}

Two English FAL workbooks, currently used in South African primary schools in Grade 4, were assessed in relation to different intelligences which are reflected through the activities learners are supposed to do. This analysis was done to find out the extent to which each workbook catered for different intelligences. For ease of reference, the two workbooks are hereinafter, referred to as Book 1 (for Terms 1 and 2) and Book 2 (for Terms 3 and 4).

For the analysis, firstly, all activities in the two workbooks were identified and written down. In this study, activities are any tasks that learners are asked to do during the learning time. These were activities that learners should do during and at the end of each lesson. Below are examples of the activities:

- Answer each of these questions.

- Encircle the letter next to the correct answer. If you are not sure what the answers are, go back and read the story again.

- Number the sentences from 1 to 5 to show the order in which things happened in the story (Book 1, p. 3).

These three activities are for one lesson and they should be done during and after the lesson. Each activity was then classified into an appropriate intelligence that aligned with it. The following are examples of the different activities whose intelligences were identified.

Example 1: Read the words and listen to the sounds. 
Then use 5 of these words to write your sentences in your exercise book (Book 1, p. 8). The activities done in this example are related to verbal/linguistic intelligence.

Example 2: Draw a line to match the present and past tense verbs (Book 2, p. 17) is intended to cater for visual-spatial intelligence.

Example 3: Work with your friends to make up a role play about what happened at Mapula's house (Book 1, p. 12). The intelligence in this activity is interpersonal.

Example 4: Fill in this mind map to show what happened in the story (Book 1, p. 12). This activity was categorized as catering for visual/spatial because learners need to think and process information in pictures and images.

\section{Findings}

The table 1 summarises the findings of the intelligences catered for in both books.

It was interesting to note that for both Books, the intelligences that were accorded the most representation were the intrapersonal and the verbal-linguistics, particularly through activities that required the learners to make up a story to show what happened in the story about the lion and the mouse; look at the pictures, they will help you fill in the missing words in this story (intrapersonal); write three sentences about each of the pictures; write opposites or antonyms for each of the sentences (verbal-linguistics). Both books were totally devoid of the musical intelligence and scantly represented the logical-mathematical intelligence; giving the impression that language learners needed not be musical or logical-mathematical in the language classroom. Such assumption further entrenches the disciplinary divides where learners should put in abeyance their logical mathematical intelligence in the language classroom and activate it in the scientific disciplines. While the naturalistic intelligence was conspicuously absent in Book 1 , it was pitifully represented in Book 2 with a single activity where learners had to research on the different dinosaurs. The visual-spatial intelligence is one intelligence that was neither overly nor under-represented in both books. Overall, the two Books similarly denied visibility to particular intelligences and accorded it to other intelligences; thereby advantaging some learners and disadvantaging other learners in the process.

\section{Discussion}

In language schools, focusing heavily on one intelligence, such as intrapersonal, does not appear to assist students in enhancing their target language competence [75]. Learners who have low intrapersonal intelligence may lose interest in studying English and develop a negative attitude toward the language.

The activities that catered for the verbal-linguistic intelligence were of a reasonable amount, accounting for $77,8 \%$ and $76,6 \%$ of the activities respectively for the two books. However, what was most expected was that verbal-linguistics intelligence takes the lead in the activities because in learning a language, in this case, English, learners have to do more of speaking, writing, and reading the language. Learning a language is done more effectively through communicating in meaningful ways using the target language [36]. Hence the development of verbal-linguistic intelligence is of utmost importance in the formation of the human being from childhood. The ability to communicate and listen has become an essential skill and as a result, verbal-linguistic intelligence becomes very important in the development of language. All intelligences play an important role in the development of an individual, but linguistic-verbal intelligence plays an important role in the development of other intelligences [38].

Table 1. Quantitative summary of the reflection of multiple intelligences in the two workbooks

\begin{tabular}{|c|c|c|c|c|}
\hline \multirow{2}{*}{ Intelligence reflected } & \multicolumn{2}{|c|}{ Book 1 [Total activities 225] } & \multicolumn{2}{c|}{ Book 2 [Total activities 197] } \\
\cline { 2 - 5 } & Number of activities & \% representation & Number of activities & \% representation \\
\hline verbal-linguistics & 175 & 77,8 & 151 & 76,6 \\
\hline logical-mathematical & 5 & 2,2 & 2 & 1 \\
\hline visual-spatial & 55 & 24,4 & 47 & 23,9 \\
\hline musical & 0 & $0 \%$ & 0 & 3 \\
\hline bodily-kinaesthetic & 7 & 3,1 & 6 & 10,2 \\
\hline interpersonal & 18 & 8 & 20 & 89,8 \\
\hline intrapersonal & 207 & 92 & 177 & 0,5 \\
\hline naturalistic & 0 & $0 \%$ & 1 & \\
\hline
\end{tabular}


Visual-spatial intelligence was catered for by only $24,4 \%$ and $23,9 \%$ of all the activities respectively. That is too low a percentage especially that these activities are meant to be done by young learners. This means most of the activities were presented with auditory rather than visual information. Hence visual-spatial intelligence learners find it more difficult to learn since the activities are traditionally focused on auditory-sequential learning [43]. Examples of the few activities that cater for visual-spatial are:

- Draw a line to match the present and past tense verbs (Book 2, p. 17).

- Encircle the words that mean the same as the first word in each row (Book 1, p. 15).

The interpersonal intelligence was catered for in only $8 \%$ and $10,2 \%$ respectively in the two books. This means there are very few activities that allow learners to interact and work together. Two of the few examples are:

- Work with your friends to make up a role play about what happened at Mapula's house (Book 1, p. 12).

- Talk to your friend about what you think these books are about (Book 2, p. 12).

Learners strong in interpersonal intelligence have a natural ability to interact with, relate to, and get along with others effectively [54]. Most of the activities in the two books do not give learners opportunities to collaborate in small groups but rather they do most of the activities individually. The small social group activities enable the learners to share information and get a better understanding of what the content is. Consequently, this relaxed and nonthreatening learning environment also allows learners receive comprehensible input by working collaboratively [56]. Unfortunately, there were a few such activities in both books.

Bodily-kinesthetic intelligence was catered for in only 3,1 and $3 \%$ of the activities respectively for the two books. The few activities include roleplaying, for example:

- Now you and your friends should pick the best ending in your group, and then make up a role-play to present your story to the class (Book 2, page 85).

- Make up a role play to show what happened in the story about the hare and the tortoise (Book 1, p. 38).

- Flip a coin. Heads you move forward 2 places, tails you move forward only one place (Book 1, p. 30).

Unfortunately, there are so limited opportunities to develop this intelligence, yet it is very important especially to young learners. [47] observed that young children process the world through the way they use their bodies, which will then become the foundation for abstract thinking. Therefore, children find it easy to grasp a lesson that is taught when they are physically involved in learning a language.

One other intelligence that was minimally catered for in the activities of both books was the logical-mathematical intelligence, accounting for only 2,2 and $1 \%$ of the activities respectively for both books. This intelligence is important because it enables learners to think conceptually and abstractly and discern logical and numerical patterns [40]. For example, in Book 1 page 42, and Book 2 page 130, learners were asked to "Do these word sums." This was the only activity that catered for the logical-mathematical learners in the two books. The same applies to naturalistic intelligence which is catered for by only $1 \%$ in Book 2 and not at all in Book 1 . The only activity that catered for this intelligence was researching a particular animal, in this case, dinosaurs, which according to [59] is an activity that caters to naturalistic intelligence.

Regrettably, neither book addressed musical intelligence, despite the fact that it is a crucial intelligence that may help children enhance their other skills, such as reasoning and problem solving, lateral thinking, memory, social skills, and teamwork [52]. This was taken for granted by the authors of the two workbooks, who overlooked musical intelligence. When working in a classroom, especially with children and adolescents, using music during instruction is highly significant since it can assist in managing their emotional states, which improves the relationship between the students.

\section{Conclusions}

The purpose of this study was to assess the extent to which Grade 4 English First Additional Language (FAL) workbooks which are currently in use in South African schools reflect multiple intelligences in the teaching and learning activities given to Grade 4 learners.

The results showed that two intelligences are predominant, and these are the intrapersonal and the verbal-linguistic intelligences. Other intelligences like visual-spatial, interpersonal, bodily-kinaesthetic, and logical-mathematical were catered for at very low level. Musical intelligence is not catered for.

These results show that the multiple intelligences theory was not taken into consideration when these workbooks were designed. The implication is that if teachers rely heavily on these workbooks, most intelligences are not developed and this will disadvantage many learners whose intelligences are not catered for. It is recommended that workbook designers take seriously the issue of multiple intelligences and ensure that they include all learners. Teachers may also be creative and cater for more intelligences as they teach so that they achieve their goals in teaching.

\section{Acknowledgement}

Thanks to Nathaniel Batidzirai for editing the constructive feedback and for editing the draft of this article. 


\section{REFERENCES}

[1] Y. Kırkgöz, Catering for multiple intelligences in locally-published ELT textbooks in Turkey, Procedia Social and Behavioral Sciences, Vol. 3, 127-130, 2010.

[2] N. Mahdi, S. Ketabi, V. D. Hossein V, Multiple Intelligences in Locally-published ELT Textbooks in Iran, MJAL Vol. 4, No. 4, 258-266, 2012.

[3] D. Boulmaiz, The Place of The Multiple Intelligences Theory in the Algerian EFL Textbook : An Evaluation of 1st Year Secondary School Textbook "At the Crossroads." Revue des sciences humaines, Vol. 8, No.1, 18-29, 2017.

[4] Ridwan, The Effectiveness of Multiple Intelligences (MI)-Based English Classroom Activities at The Eleventh Grade Students of SMAN 2 Mamuju of West Sulawesi. ELT Worldwide, Vol. 2 No. 2, 126-144, 2015.

[5] M. Gonzalez-Trevino, G.M. Mayela Nú nez-Rocha, J. M. Valencia-Hernandez, A. Arrona-Palacios, Assessment of multiple intelligences in elementary school students in Mexico: An exploratory study. Heliyon Vol. 6, 1-5, 2020.

[6] Ernawati, H. Tsurayya, A. R. Ghani, Multiple intelligence assessment in teaching English for young learners. Research and Evaluation in Education, Vol. 5. No. 1, 21-29, 2019.

[7] H. Gardner, Multiple intelligences: The theory in practice, Basic Books, 1993.

[8] H. E Gardner, Intelligence reframed: Multiple intelligences for the 21 st century. Hachette UK, 2000.

[9] N. L. Mingchu, H. Mindy, ESL teachers' multiple intelligences and teaching strategies: Is there a linkage? TESOL Journal, Vol. 10. 2018. DOI:10.1002/tesj.379

[10] L. Kennedy-Murray, Teachers' Perceptions and Practices of Multiple Intelligences Theory in Middle Schools. Doctoral Thesis. Walden University, 2016.

[11] R.E. Carlín, M. Salazar, S. Cortés, A Mexican Study of Multiple Intelligences for Pre-Service Teachers of English as a Foreign Language, HOW, Vol. 20, 170-189, 2013.

[12] R. Faidah, E. Fauziati, S. Suparno, Teachers' beliefs on multiple intelligence based English teaching for young learners. Exposure: Jurnal Pendidikan Bahasa dan Sastra Inggris, Vol. 8, No.1, 60-72, 2019.

[13] Alez-Treviño, G. Núñez-Rocha, J. Valencia-Hernández, A. Arrona-Palacios, Assessment of multiple intelligences in elementary school students in Mexico: An exploratory study, Heliyon 6, 2020. e03777. 10.1016/j.heliyon.2020.e0 3777 .

[14] N. Tsuda, The Theory of Multiple Intelligences and Its Application in EFL Classrooms. Language and Culture, The Journal of the Institute for Language and Culture, Vol.12, 31-43, 2008. Retrieved April 23, 2019, from <www.konan-u.ac.jp/kilc/modules/info/src/tuda/3.pdf>.

[15] Z. Dolati, A. Tahriri, EFL Teachers' Multiple Intelligences and Their Classroom Practice, SAGE Open, 7. 2017.

[16] Abdi, M. Rostami, The effect Multiple intelligences- based instruction on Students' creative thinkingability at 5th grade in primary school, Procedia - Social and Behavioral Sciences, Vol. 47, 105 - 108, 2012.

[17] S. Coban, O. Dubaz, The relationship between active learning models in music lessons in elementary schools and multiple intelligence areas, Procedia - Social and Behavioral Sciences, Vol. 28, 684 - 690, 2011.

[18] E. Tsurayya, A. R. Ghan, Multiple intelligence assessment in teaching English for young learners, Research and Evaluation in Education, Vol. 5, No. 1, 21-29, 2019. Available online at: http://journal.uny.ac.id/index.php/reid

[19] Derakhshan, M. Faribi, Multiple Intelligences: Language Learning and Teaching, International Journal of English Linguistics, Vol 5. No 4, 63-72, 2015. https://doi.org/10.5539/ijel.v5n4p63

[20] T. Sulaiman, A. Hassan, H. Y. Yi, An Analysis of Teaching Styles in Primary and Secondary School Teachers based on the Theory of Multiple Intelligences, Journal of Social Sciences, Vol. 7, No. 3, 428-435, 2011.

[21] R. A. Yaghoob, Z. P. Hossein, The correlation of multiple intelligences for the achievements of secondary students. Educational Research and Reviews, Vol.11, No. 4, 141$145,2016$.

[22] M.C Maphalala, N. Mpofu, Assessing multiple intelligences (MI) through the South African curriculum and assessment policy statement. The Online Journal of New Horizons in Education, Vol. 7, No. 2, 46-53, 2017.

[23] H. C Pienaar, M. M. Nieman, G. D. Kamper, Implementing a teaching approach based on the multiple intelligence theory in a South African school: A case stud. Africa Education Review, Vol. 8, No. 2, 267-285, 2011. DOI: $10.1080 / 18146627.2011 .603235$.

[24] E. Gouws, A. M. Dicker, Teaching Mathematics that Addresses Learners' Multiple Intelligences, Africa Education Review, Vol. 8, No. 3, 568-587, 2011.

[25] F. E. Gouws, Teaching and learning through multiple intelligences in the outcomes-based education classroom, Africa Education Review, Vol. 4, No. 2, 60-74, 2007. DOI:10.1080/18146620701652705

[26] M. De vries, The role of the Foundation Phase teacher in facilitating multiple intelligences in the classroom, Masters Thesis, University of South Africa, South Africa, 2014.

[27] Y. Taase, Multiple intelligence theory and Iranian textbooks: An analysis, Journal of Pan-Pacific Association of Applied Linguistics, Vol. 16, No.1, 73-82, 2012.

[28] A.S. Fawzia, A. Hind, Multiple Intelligences in the Omani EFL context: How Well Aligned are Textbooks to Students' Intelligence Profiles? International Journal of Learning. Teaching and Educational Research, Vol. 15. No. 5, 128-139, 2016.

[29] Y. T. Mengesha, Implications of multiple intelligence theory and integrated skills language teaching for textbook development, University of South Africa, Pretoria, 2016. http://hdl.handle.net/10500/20104

[30] T. Al-Omari, R. Bataineh, R, O. Smadi, Potential Inclusion of Multiple Intelligences in Jordanian EFL Textbooks: A Content Analysis, Bellaterra Journal of Teaching \& 
Learning Language \& Literature, Vol. 8, No. 1, 60-80. 2015.

[31] C. Mullican, Multiple Intelligences in the Text: Examining the Presence of Multiple Intelligences Tasks in the Annotated Teacher's Editions of Four High School United States History Textbooks. Doctoral Thesis, College of Education: University of South Florida, 2012.

[32] H. Gardner, Frequently asked questions-Multiple intelligences and related educational topics, 2013. Retrieved fromhttps://howardgardner01.files.wordpress.co m/2012/06/faq march2013.pdf

[33] H. Gardner, Intelligence reframed: Multiple intelligences for the 21st century. Basic Books. 1999

[34] T. Armstrong, Multiple intelligences in the classroom (3rd ed.), Alexandria, VA: ASCD, 2009.

[35] H. Gardner, The theory of multiple intelligences: As psychology, as education, as social science, Address delivered at José Cela University on October, 29, 2011.

[36] H. Husarida, R. Dollete, Perceived Effectiveness on the Use of English Language in Teaching Mathematics and Science. Indonesian Research Journal in Education, Vol. 3, No1, 177-198, 2019. https://doi.org/10.22437/irje.v3i1.696 1

[37] B. Armel, Literasi dengan empat keterampilan berbahasa. IGI Ikatan Guru Indonesia, 2016. www.igi.or.id tanggal 26 Januari 2017

[38] N. Hali, The Actualization of Literary Learning Model Based on Verbal-Linguistic Intelligence, International Journal of Education \& Literacy Studies, Vol . 5, No. 4, 42-48, 2017.

[39] Hammoudi, Multiple intelligences and teaching. English as a foreign language, the case of second-year pupils at Malika gaid secondary school Setif (Master's thesis), Ferhat Abbes Unversity, Setif, Algeria, 2010.

[40] Chapman, If the shoe fits...How to Develop Intelligences in the classroom. Glenview: Pearson, 1993.

[41] R. Nur, T. Herman, R. Mariyana, Logical Mathematics Intellegence in Early Childhood Students, International Journal of Social Science and Humanity, Vol. 8, No. 4, 105-109, 2018

[42] H. Sri, Logical mathematical intelligence toward students participation and character building in Indonesia, ICTESS, Vol. 1, No.1, 2017.

[43] J. Safranj, J. Zivlak, Spatial-visual intelligence in teaching students of engineering. Research in Pedagogy, Vol. 8. No. 1, 71-83, 2018. doi:10.17810/2015.72

[44] K. S. Ibmian, A. D. Hadban, Implications of multiple intelligences theory in ELT field. International Journal of Humanities and Social Science, Vol. 3, No. 4, 292-297, 2013.

[45] S. Franceschini, S. Gori, M. Ruffino, K. Pedrolli, A. Facoetti, A causal link between visual spatial attention and reading acquisition. Curr Biol, Vol. 22, No.9, 814-9. 2012.

[46] Y. L. Cheng, K. S. Mix, Spatial training improves children's mathematics ability, Journal of Cognition and Development, Vol. 15, No. 1, 2013.
DOI:10.1080/15248372.2012.72518.

[47] M.D. Lash, Multiple intelligences and the search for creative teaching. Paths of Learning, Vol. 22, 13-15, 2004.

[48] M. Khitam, K. Mansi, M. H. Abu Al-Taieb, Z. M. Ermeley, M. M. Bayyat, T. Aburjai, Bodily-kinesthetic intelligence in relation to swimming performance skills according to gender and swimming course level among physical education students. "Sport Medicine Journal" No.50, 2018.

[49] M. A. Christison, Teaching and Learning Languages through MI. TESOL Journal, Vol. 6 No.1, 10-14, 1996.

[50] E. G. Schellenberg, Long-term positive associations between music lessons and IQ, Journal of Educational Psychology, Vol. 98, No. 2, 457-468, 2006. https://doi.org/10.1037/0022-0663.98.2.457

[51] D. Levitin, El cerebro musical: seis canciones que explican la evolución humana. Barcelona: RB, (2014.

[52] T. García-Vélez, A. Maldonado Rico, Reflexiones sobre la inteligencia musical. Reflections on musical intelligence, Revista Española de Pedagogía, Vol.75, No. 268, 451-461, 2017. doi: https://doi.org/10.22550/REP75-3-2017-08

[53] C. Toscano-Fuentes, M. Fonseca-Mora, M, La música como herramienta facilitadora del aprendizaje del inglés como lengua extranjera.Teoría de la Educación. Revista Interuniversitaria, Vol. 24, 2, 197-213, 2012. Retrieved from

http://revistas.usal.es/index.php/1130-3743/article/view/10 361

[54] V. Advani, G. Hema, Effect of Interpersonal Intelligence Based Teaching Strategies on Students Academic Achievement, International Journal of Indian Psychology, Vol. 3, 119-128, 2016.

[55] V. M. Bhana, Interpersonal Skills Development in Generation Y Student Nurses: A Literature Review Nurse Education Today, Vol. 34, 1430-1434, 2014.

[56] M. Hajebi, S. Taheri, M. Noshadi, The Relationship between Interpersonal Intelligence, Reading Activity and Vocabulary Learning among Iranian EFL Learners. International Journal of English Language \& Translation Studies, Vol. 6, No. 1, 48-56, 2018.

[57] McKay, Multiple Intelligences, Encyclopedia of Educational Psychology, USA, Vol. 2, 712-717, 2008.

[58] H. Gardner, Multiple intelligences new horizons. New York, New York: Basic Books, 2006.

[59] D. Connell, Brain-Based Strategies to Reach Every Learner, New York: Scholastic, 2005.

[60] H. Gardner, Frames of mind: the theory of multiple intelligences (10thed), New York, NY: Basic Books, 2011a.

[61] J. Hattie, Visible Learning for Teachers: Maximizing Impact on Learnin, New York, NY: Routledge, 2011.

[62] C. A. Tomlinson, The Differentiated Classroom: Responding to the Needs of All Learner, Alexandria, VA: ASCD, 2014.

[63] T. Armstrong, Multiple Intelligences in the Classroom (4th Edition) Alexandria, VA: Association for Supervision and 
Curriculum Development, 2018.

[64] E. Dylan, Integrated curricular approaches in reaching adult students. Adult Learning, Vol. 24, No. 3, 128-130, 2013.

[65] P. Savas, Pre-service English as a foreign language teachers' perceptions of the relationship between multiple intelligences and foreign language learning. Learning and Individual Differences, Vol. 22, No. 6, 850-855, 2012.

[66] J. Sibanda, L. Sibanda, Linguistic Gender Sensitivity Strategies in Current South African Intermediate Phase English Workkbooks: Feminisation or Degenderisation? Africa Education Review, Vol. 13, No.3, 104-118, 2016. DOI:10.1080/18146627.2016.1224554

[67] L. Sibanda, Grade 4 Learners' Linguistic Difficulties in Solving Mathematical Assessments, African Journal of Research in Mathematics, Science and Technology Education, Vol. 21, No. 1, 86-96, 2017. DOI: $10.1080 / 18117295.2017 .1291476$

[68] DBE (Department of Basic Education), Workbooks, 2015. http://www.education.gov.za/Curriculum/Workbooks/tabid /574/Default.aspx

[69] DBE, The Rainbow Workbooks, 2011. Retrieved from http://www.ar-t.co.za/DOEFlyer/

Workbooks\%20flyer\%201706.pdf (accessed 1 Dec 2021).
[70] L. Sibanda, Impact of linguistic complexity in English language texts on South Africa's primary school grade 3 to 4 transition, Issues in Educational Research, Vol. 30, No. 2, 673-690, 2020. http://www.iier.org.au/iier30/sibanda.pdf

[71] B. Fleisch, N. Taylor, R Herholdt, I Sapire, Evaluation of Back to Basics mathematics workbooks: a randomised control trial of the primary mathematics research project1, South African Journal of Education, Vol.31, No.4, 489-504, 2011.

[72] N. Stein, "Textbooks", In F. Veriava , A. Thom, T. Hodgson (eds) Basic education rights handbook: Education rights in South Africa, Johannesburg : Section 27, 263-273. 2017.

[73] U. Hoadley, J. Galant, 'An analysis of the Grade 3 Department of Basic Education workbooks as curriculum tools', South African Journal of Childhood Education Vol.6, No. 1, a400. 2016. http://dx.doi.org/10.4102/sajce.v $6 \mathrm{i} 1.400$

[74] C. Mathews, M. Mdlulu, V. Ramsingh, 'The use of workbooks in South African grade 3 mathematics classrooms', South African Journal of Childhood Education Vol.4, No.1, 80-94, 2014.

[75] H. Puchta, M. Rinvolucri, Multiple intelligences in EFL: Exercises for secondary and adult students, West Sussex, England: Helbling Languages, 2005. 